\title{
Palaeoecology of Late Triassic conodonts: Constraints from oxygen isotopes in biogenic apatite
}

\author{
Manuel Rigo and Michael M. Joachimski \\ Acta Palaeontologica Polonica 55 (3), 2010: 471-478 doi: http://dx.doi.org/10.4202/app.2009.0100
}

The oxygen isotopic composition of conodont apatite derived from the Late Triassic (Carnian to lower Norian), Pignola 2 and Sasso di Castalda sections in the Lagonegro Basin (Southern Apennines, Italy) was studied in order to constrain the habitat of Late Triassic conodont animals. Oxygen isotope ratios of conodonts range from 18.5 to $20.8 \%$ V-SMOW, which translate to palaeotemperatures ranging from 22 to $31^{\circ} \mathrm{C}$, assuming a $\delta^{18} \mathrm{O}$ of Triassic subtropical sea water of $-0.12 \%$ V-SMOW. These warm temperatures, which are well comparable to those of modern subtropical-tropical oceans, along with the body features of the conodont animal suggest that conodont $\delta^{18} \mathrm{O}$ values reflect surface water temperatures, that the studied conodont taxa lived in near-surface waters, and that $\delta^{18} \mathrm{O}$ values of Late Triassic conodonts can be used for palaeoclimatic reconstructions.

Key words: Conodonta, palaeoecology, oxygen isotope, palaeotemperatures, Late Triassic, Tethys.

Manuel Rigo [manuel.rigo@unipd.it], Department of Geosciences, University of Padova, Via Giotto 1, 35121 Padova, Italy (corresponding author) and Michael M. Joachimski [joachimski@geol.uni-erlangen.de], GeoZentrum Nordbayern, University of Erlangen-Nürnberg, Schlossgarten 5, 91054 Erlangen, Germany.

This is an open-access article distributed under the terms of the Creative Commons Attribution License (for details please see creativecommons.org), which permits unrestricted use, distribution, and reproduction in any medium, provided the original author and source are credited. 